\title{
Perception of Values in Prospective Teachers
}

\author{
Dr. Sana Ali Rachamalla \\ Department of English Languge \\ Deanship of Preparatory Year \\ Imam Abdulrahman Bin Faisal University, Dammam, Saudi Arabia \\ sarachamalla@iau.edu.sa
}

Dr. Anjali Hans

ELPD Trainer Cum Content Writer, Chandigarh University, Mohali, Punjab, India dcpd.elpd25@cumail.in

\begin{abstract}
Prospective teachers are those teachers who are looking towards the future. Prospective teachers are to be competent in the profession and losing belief in the profession. Prospective teachers are able to incorporate in their teaching cross-circular dimensions and themes, including environmental education. There is constant change in the society in respect to values, norms, ideals as well as attitudes of the individual which make the society more complex and integrated. Values are important because every human action is the reflection of an individual value and every human institution is the outgrowth of social values. Generally speaking, values are the norms of behavior which have been evolved during the course of time in the social, moral and spiritual fields. Values are conscious and unconscious preferences, accepted by the majority of members of the socially regulated. The purpose of this study was to explore the level of perception of values of prospective teachers of colleges of education and find out the differences, if any, in terms of gender, locality of colleges and nature of colleges in their perception of values. A sample of 40 prospective teachers was collected from different colleges located in rural and urban areas of Mohali District of Punjab state. The t-test and ANOVA test were used for analyzing the data. The prospective teachers of town are better in neighbourly values than the prospective teachers of village. The prospective teachers of village are better in perception of social values than the prospective teachers of town.
\end{abstract}

Key words: Prospective Teachers, Values, Quality Teachers, Value Perception 


\section{Introduction}

Prospective teachers need a range of literary experience matching that of the society and some sense of which works should come first for the growth of each particular student. A prospective teacher is usually required to complete an accelerated university program, pass the state licensing test, and submit to a series of interviews. Some qualities of a good teacher include skills in communication, listening, collaboration, adaptability, empathy and patience. Other characteristics of effective teaching include an engaging classroom presence, value in real-world learning, exchange of best practices and a lifelong love of learning. Teacher's role is very vital in moulding the future of a country, and as such it is considered as the noblest profession. Generally, it is said that, what a teacher says, what a teacher does; doing aspect is more effective than his saying. The Values are Codes of conduct. The knowledge of values is the theoretical aspect; the conduct is the operative aspect of values which is essential for inculcating values among students. The values are inculcated inside the classroom and outside the classroom in a school. A teacher has to generate a conducive environment in the classroom as well as outside the class and shows an ideal model of his/her behaviour for inculcating values among his/her students. For inculcating values among students, a teacher himself/herself be a role model and a person imbibed with values.

Teachers are expected to have a wide range of knowledge, skills and competences, and to respond to a diversity of tasks they carry out in schools. The profession of teaching is becoming more and more complex. A high quality of initial teacher education is crucial for the possibilities of teachers to face the demands they confront with, in terms of knowledge of academic subjects and pedagogical skills. In order to prepare the students better for the demands of their future profession, the teacher education program offered at universities (which are usually theoretical, abstract) should promote more opportunities for students to apply the skills involved in a professional teacher activity. This is also important for reducing "reality or practice shock" (Stokking, Leenders, De Jong \& Van Tartwijk, 2003), that many prospective teachers experience in their first lessons. Collaborative skills are a critical requirement for most employees. Learning to work well with others should not be an on-thejob experience (Snyder, McNeil, 2008). Students need to develop group work skills before they face the real work world. These considerations inspired us to develop an instructional context where prospective teachers could benefit from practical preparation and collaborative working, in order to prepare them better for the demands of their future profession.

"The great travesty of humanity is the fact that we are created in the image and likeness of God, yet we destroy each other, and this is a contradiction to a very essence of our creation." Charles Lutes (2001). Human life has its worth only when it is lived meaningfully and satisfactorily. It revolves around the axis of relationships with his fellow beings and environment. At the root of these relationships, lie the values of a person, cherished by him within his heart. Values are our codes of internal conduct, the principles upon which we run our lives and make our decisions. In other words, behavior is always based on choices and choices are based on values; values are the basic convictions that give us a sense of right or wrong, good or bad. To put in the words of Charlie Lutes (2002)." That which helps us to 
grow is of great value. False values are those things that do not lead us upward, or help us to establish our own integrity and to grow." Our first values are given to us by our parents and these are added to by those values given to us by our peers, our teachers and the wider community. Human values have an inherent dynamism which carries the human being forward through all the domains of the person to the exercise and application of knowledge, skill and attitude. Hence it is evident that human values are eternal essences empowering, driving, charging and informing human activity which sustain and uplift bot the individual and the society.

\section{Review of Related Studies}

The review of related literature enables the researcher to define the limits of his field. It helps the researcher to acquire up-to-date information about what has been thought and done on the particular area from which he intends to make up a problem for research. It provides ideas, theories, explanations, hypotheses or methods of research valuable in formulating the study Munir, Ahmad and Shahzadi (2011) conducted a study on academic dishonesty of university students with the objective to classify the cases into three groups of free-riders (never, sometimes, always) on the basis of different factors of academic dishonesty by using discriminant analysis. Two Hundred samples were selected for the study from the population of 6749 students of University of Gujarat. The results show that the most important academic dishonesties are Sabotage, Electronic Cheating and Outside Help.

Texas Tech University's in connection with Arbor Day Celebration (2012), with the Texas Tech University Ethics Center administered a written assessment of students' understanding of academic integrity. To keep students from answering in a way they think might be expected, the survey was anonymous. Completed surveys were analyzed by the Texas Tech University Ethics Center. The result showed that the students have good comprehension of academic integrity and plagiarism' and 'collusion' are the areas that students wanted to learn more.

David (2015) conducted a study to find the relation among personal values, self-esteem and mastery in academic cheating. It was found that self-esteem and mastery feeling is negative associated with cheating. Small, negative correlations were obtained between cheating and values placed on honesty and academic achievement. Students with a more optimistic view on human nature cheat less, but there was no relation between the cynic ones and cheating.

Moris (2018) through her commentary paper studies the grave issue of contract cheating in higher education. The paper also examined significant concerns about students' use of academic writing services, along with sector and national calls for action that would lead to making writing illegal. This paper also focuses on how universities and colleges can react to such type of alarming situations .The paper also recommends that the universities and institutions may also propose, extend and establish strategies to embed the values, principles and practices associated to academic integrity. As part of this endeavour, the author proposes five areas of consideration for higher education institutions that relate to: determining 
academic integrity strategy; reviewing institutional policy; understanding students; re-visiting assessment practices; and implications for staff professional development.

\section{Need and significance of the study}

There has been a rapid deterioration of ethical and moral values in the society. The quality of a nation depends upon the quality of its citizens. The quality of the citizens depends upon the quality of education and the quality of education depends upon the "Quality Teachers". Teacher's role is very vital in moulding the future of a country, and as such it is considered as the noblest profession. Generally, it is said that, what a teacher says, what a teacher does; doing aspect is more effective than his saying. The doing aspect evolves emotions and activity which is known as conduct. The Values are Codes of conduct. The knowledge of values is the theoretical aspect; the conduct is the operative aspect of values which is essential for inculcating values among students. The values are inculcated inside the classroom and outside the classroom in a school. A teacher has to generate a conducive environment in the classroom as well as outside the class and shows an ideal model of his/her behaviour for inculcating values among his/her students. For inculcating values among students, a teacher himself/herself be a role model and a person imbibed with values. As such to study the different value patterns of the prospective teachers, the present study has been undertaken.

Values are dynamic and fluid; they are not discrete units but multi layered, multi-contextual and multi-faceted. They do not have rigid boundaries rather apply across all compartments of behavior, choice and motivation. We know that action behaviors are based on thoughts, which express wants ad desires. Therefore right values at the right time at the right place have to be implanted in the younger minds of our country and the educational institutions become the apt hub of citizen training. For Vivekananda (1897), the aim of education is the making of whole human being: this is supported by Mahatma Gandhi who says that education aims at the development of 3Hs-head, heart and hand. Thus, education becomes not mere acquisition of knowledge or correlating facts but also of imbibing values for human living. J. Ruskin would say," Education does not mean teaching people to know what they do not know; it means teaching them to behave as they do not behave, thus ultimate aim of education is to achieve good life." After home, school is the next learning environment for the child and teacher are the second parents. Teaching is not a job, it is an attitude. An ideal teacher is a source of information, a guide, a mentor, a role model and a motivator at all the same time. Teaching is the only profession which always deals with the future. If a teacher is able to exhibit proper attitude through his behavior, then his students would be the best products for the country; which means the formation of prospective teachers is to be evaluated frequently so that the cultivation of values is done in the schools without any hindrance. Thus it has become necessary to study the level of perception of values by prospective teachers so that relevant suggestions may be placed with officials for better grooming of future citizens. 


\section{Objectives}

This study has the major objectives as follows:

1- To find out the level of value perception of prospective teachers in terms of a few background variables.

2- To find out the difference among the prospective teachers in their perception of values and its dimensions in terms of gender, locality and nature of colleges of education.

\section{Hypotheses}

1- There is no significant difference between male and female prospective teachers in their perception of personal, neighbourly and social values.

2- There is no significant difference between town and village prospective teachers in their perception of personal, neighbourly and social values.

3 - There is no significant difference among prospective teachers of men, women and coeducation colleges of education in their perception of personal, neighbourly and social values.

\section{Methodology}

The survey method was followed for this investigation. Since it is a fact finding expedition, this method was adopted by the investigator.

\section{Population}

The population for this study is formed with the total number of prospective teachers who had chosen the punjabi as optional subject in various colleges of education at Mohali District.

\section{Sample}

The sample selected for this study consists of 40 prospective teachers, studying in different colleges of education located at Mohali district, Punjab. Here random sampling method was followed. Among forty teachers, there were 19 men and 21 women prospective teachers and there were 21 from rural and 19 from urban locations.

\section{Description of the Tool}

The investigator used the Value perception scale prepared by Amalorpavam and Annaraja (2012). The scale had its content validity checked by various educationists and later 60 items were selected out of 96 items through item analysis. The value perception scale had three dimensions namely personal, social and neighbourly values with 60 positive items; the respondents were asked to select one out of five options, where the first indicated the total disagreement with statement and the fifth totally agreeing with content in the tool. The score varied from 1 to 5 . The reliability of the tool was found out to be 0.78 through test- retest method.

\section{Statistical Technique}

For analyzing the data, statistical technique like t-test and analysis of variance (ANNOVA) were used. 


\section{Analysis}

The analysis has been given in the following tables.

Table -01

Level of Value Perception

\begin{tabular}{|l|l|l|l|l|l|l|l|}
\hline \multirow{2}{*}{ S.No. } & Value perception and its & \multicolumn{2}{l|}{ Low } & \multicolumn{2}{l|}{ Moderate } & \multicolumn{2}{l|}{ High } \\
\cline { 3 - 8 } & dimensions & $\mathrm{N}$ & $\%$ & $\mathrm{~N}$ & $\%$ & $\mathrm{~N}$ & $\%$ \\
\hline 1. & Personal Values & 6 & 15 & 26 & 65 & 8 & 20 \\
\hline 2. & Neighbourly Values & 8 & 20 & 28 & 70 & 4 & 10 \\
\hline 3. & Social Values & 11 & 27.5 & 21 & 52.5 & 8 & 20 \\
\hline 4. & Value Perception & 8 & 20 & 26 & 65 & 6 & 15 \\
\hline
\end{tabular}

It is inferred from the above table that $15 \%$ of prospective teachers have low, $65 \%$ of them have moderate and $20 \%$ of them have high level of perception of Personal Values; $20 \%$ of prospective teachers have no, $70 \%$ of them have moderate and $10 \%$ of them have high level of perception of neighbourly values; $27.5 \%$ of prospective teachers have low, $52.5 \%$ of them have moderate and $20 \%$ of them have high level of perception of social values, and $20 \%$ of prospective teachers have low, $65 \%$ of them have moderate and $15 \%$ of them have high level of perception of in total.

\section{Null hypothesis 1}

There is no significant difference between male and female prospective teachers in their perception of personal, neighbourly and social values.

Table -02

Difference between Male and Female Prospective Teachers in their Value Perception and its Dimensions

\begin{tabular}{|c|c|c|c|c|c|c|c|}
\hline \multirow[t]{2}{*}{ S.No } & \multirow[t]{2}{*}{$\begin{array}{l}\text { Value perception } \\
\text { and its dimensions }\end{array}$} & \multicolumn{2}{|c|}{ Male ( $N=19)$} & \multicolumn{2}{|c|}{$\begin{array}{l}\text { Female( } \quad \mathrm{N}= \\
21)\end{array}$} & \multirow[t]{2}{*}{$\begin{array}{l}\text { Calculated } \\
\text { value of " } t \text { ' }\end{array}$} & \multirow{2}{*}{$\begin{array}{l}\text { Remarks at } \\
5 \% \\
\text { Level }\end{array}$} \\
\hline & & Mean & SD & Mean & $\mathrm{SD}$ & & \\
\hline 1. & Personal Values & 50.38 & 11.20 & 49.80 & 9.14 & 0.18 & NS \\
\hline 2. & $\begin{array}{l}\text { Neighbourly } \\
\text { Values }\end{array}$ & 50.15 & 10.46 & 48.50 & 10.79 & 0.49 & NS \\
\hline 3. & Social Values & 49.80 & 8.90 & 50.06 & 11.70 & 0.08 & NS \\
\hline 4. & Value Perception & 5018 & 10.65 & 49.06 & 9.89 & 0.35 & NS \\
\hline
\end{tabular}

(At $5 \%$ level of significance the table value of ' $t$ ' is 1.96)

It is inferred from the above table that there is no significant difference between male and female prospective teachers in their perception of personal, neighbourly, social values and value perception.

\section{Null hypothesis 2}

There is no significant difference between town and village prospective teachers in their perception of personal, neighbourly and social values. 
Table - 03

Difference between Town and Village Prospective Teachers in their Perception of value perception and in Dimensions

\begin{tabular}{|c|c|c|c|c|c|c|c|}
\hline \multirow[t]{2}{*}{ S.No. } & \multirow{2}{*}{$\begin{array}{l}\text { Value } \\
\text { perception and } \\
\text { its dimensions }\end{array}$} & \multicolumn{2}{|c|}{$\operatorname{Town}(\mathrm{N}=21)$} & \multicolumn{2}{|c|}{$\begin{array}{l}\text { Village( } \\
\mathrm{N}=19)\end{array}$} & \multirow[t]{2}{*}{$\begin{array}{l}\text { Calculated } \\
\text { value of } t\end{array}$} & \multirow[t]{2}{*}{$\begin{array}{l}\text { Remarks at } \\
5 \% \text { Level }\end{array}$} \\
\hline & & Mean & $\mathrm{SD}$ & Mean & SD & & \\
\hline 1 & $\begin{array}{l}\text { Personal } \\
\text { Values }\end{array}$ & 52.31 & 9.83 & 47.59 & 9.93 & 1.51 & $\mathrm{NS}$ \\
\hline 2. & $\begin{array}{l}\text { Neighbourly } \\
\text { Values }\end{array}$ & 52.65 & 9.23 & 45.56 & 10.86 & 2.21 & NS \\
\hline 3. & Social Values & 46.67 & 9.60 & 53.55 & 10.13 & 2.20 & $\mathrm{NS}$ \\
\hline 4. & $\begin{array}{l}\text { Value } \\
\text { Perception }\end{array}$ & 50.67 & 10.32 & 48.38 & 10.08 & 0.71 & NS \\
\hline
\end{tabular}

(at $5 \%$ level of significance the table value of ' $t$ ' is 1.96)

It is inferred from the above table that there is no significant difference between town and village prospective teachers in their perception of personal values and value perception in total but there is significant difference between town and village prospective teachers in their perception of neighbourly and social values. While comparing the mean scores of town and village prospective teachers (mean is 52.65) are better in neighbourly values than the village prospective teachers (mean is 45.46). While comparing the mean scores of town and village prospective teachers, the village prospective teachers (mean is 53.55) are better in perception of social values than the town prospective teachers (mean is 46.67)

\section{Null hypothesis 3}

There is no significant difference among prospective teachers of men, women and coeducation colleges of education in their perception of personal, neighbourly and social values.

Table -04

Difference among Men, Women and Co-Education College Prospective Teachers in their Value Perception and its Dimensions

\begin{tabular}{|c|c|c|c|c|c|c|c|}
\hline S.No. & $\begin{array}{l}\text { Value } \\
\text { Perception } \\
\text { and its } \\
\text { dimensions }\end{array}$ & $\begin{array}{l}\text { Source } \\
\text { of } \\
\text { variation }\end{array}$ & $\begin{array}{l}\text { Sum of } \\
\text { squares }\end{array}$ & $\begin{array}{l}\text { Degree } \\
\text { of } \\
\text { freedom }\end{array}$ & $\begin{array}{l}\text { Variance } \\
\text { estimate }\end{array}$ & $\begin{array}{l}\text { Calculated } \\
\text { ' } F \text { ' value }\end{array}$ & $\begin{array}{l}\text { Remarks } \\
\text { at } 5 \% \\
\text { Level }\end{array}$ \\
\hline \multirow[t]{2}{*}{1} & \multirow{2}{*}{$\begin{array}{l}\text { Personal } \\
\text { Values }\end{array}$} & Between & 13262 & 2.00 & 66.31 & \multirow[t]{2}{*}{0.65} & \multirow[t]{2}{*}{ NS } \\
\hline & & Within & 3797.78 & 37.00 & 102.64 & & \\
\hline \multirow[t]{2}{*}{2} & \multirow{2}{*}{$\begin{array}{l}\text { Neighbourly } \\
\text { Values }\end{array}$} & Between & 21.67 & 2.00 & 10.83 & \multirow[t]{2}{*}{0.09} & \multirow[t]{2}{*}{$\mathrm{NS}$} \\
\hline & & Within & 4304.86 & 37.00 & 116.35 & & \\
\hline \multirow[t]{2}{*}{3} & \multirow{2}{*}{$\begin{array}{l}\text { Social } \\
\text { Values }\end{array}$} & Between & 2.50 & 2.00 & 1.25 & \multirow[t]{2}{*}{0.01} & \multirow[t]{2}{*}{$\mathrm{NS}$} \\
\hline & & Within & 4159.84 & 37.00 & 112.43 & & \\
\hline \multirow[t]{2}{*}{4} & \multirow{2}{*}{$\begin{array}{l}\text { Value } \\
\text { Perception }\end{array}$} & Between & 92.09 & 2.00 & 46.04 & \multirow[t]{2}{*}{0.43} & \multirow[t]{2}{*}{ NS } \\
\hline & & Within & 3917.63 & 37.00 & 105.88 & & \\
\hline
\end{tabular}

(at $5 \%$ level of significance, the table value of ' $\mathrm{F}$ ' is 3.26) 
It is inferred from the above table that there is no significance difference among prospective teachers of men, women and co-education colleges in their perception of personal, neighbourly and social values.

\section{Findings of the study}

1- The prospective teachers seem to have high level of perception of personal and social values.

2- There is no significant difference between male and female prospective teachers in their perception of personal, neighbourly and social values.

3- The town prospective teachers are better in neighbourly values than the village prospective teachers and the village prospective teachers are better in perception of social values than the town prospective teachers.

4- There is no significant difference among prospective teachers of men, women and coeducation colleges in their perception of personal, neighbourly and social values.

\section{Interpretation}

It is a disturbing phenomenon to read that the prospective teachers have a low level of neighbourly values; this may be due to lack of motivation and basic conviction that is to be reminded often by the authority. The teachers are expected to serve the country and teaching is the noblest service; they should be instructed on the holiness of the job of teaching when they choose this career. The teachers are to be role models is exhibiting right values at right situation in an appreciable manner. The neighbourly values must be their identity and needed a serious effort in reviving the spirit of broad mindedness and unity. The prospective teachers of the town are better in their perception of neighbourly values than the prospective teachers of the villages and this may be due to better exposure to the society through media and other newly developed technology for teachers from town.

The village prospective teachers are better in their perception of social values than the town prospective teachers and this is supported by the research done by Kanwar Jasminder Palsingh (2004) who found out that village teachers were better than town prospective teachers. This may be due to traditional outlook of brotherliness experienced among the village people, transcending the narrow borders of caste, colour and creed. They cherish oneness and appreciate the unity in all the ways possible. That is why all the events in the villages are celebrated than being merely attended.

\section{Conclusion}

The perception of values by a teacher is an important aspect of being an efficient and effective teacher, unless the teacher has the thirst for social justice and social commitment, the wards will not have an inclination for the same. Only when we have pure thoughts it is represented through right actions; this right attitude comes out of the values that won cherishes in his life. It is very much essential that the teacher is value-oriented so that his or her service becomes relevant for the younger generation. Nurturing the personal neighbourly and social values among the prospective must be given utmost priority in the training period 
of prospective teachers. The management and the government authorities must create opportunities for more inter personal relationship and interaction with the society; though there is a programme of social service in villages, it is not properly oriented or effectively organized and hence it has minimum impact in the social attitude of the prospective teachers. Furthermore group events must be conducted free sharing among the trainees so that they are able to go beyond their narrow thinking and prejudices, related with past experiences. More number of intercollegiate cultural and academic programme could be arranged to enthuse the simple and the rural young prospective teachers to come out of their shells. The prospective teachers, if they are cared for, then the future generation is well- protected.

\section{References}

1- Arulsamy.S, (2013), peace education and value education, New Delhi: Neel Kamal publications.

2- ChittiBabu.S.V (2009), Higher Education in India: Issues and Imperatives, Chennai: Palaniappa Brothers.

3- Calderhead, J., \& Robson, M. (1991). Images of teaching: Student teachers' early conceptions of classroom practice. Teaching and Teacher Education, 7, 1-8.

4- Connell, R. (1995). Transformative labour: Theorizing the politics of teachers' work. In M.B. Ginsburg (Ed.), The politics of educators' work and lives (p. 91-114). New York: Garland Publishing.

5- Council of Chief State School Officers. (2011). Interstate Teacher Assessment and Support

6- Consortium (InTASC) Model Core Teaching Standards: A resource for state dialogue. Washington, DC: Author.

7- Danielson, C., \& McGreal, T. (2000). Teacher evaluation to enhance professional practice. Princeton, NJ: Educational Testing Service.

8- Dick, T.P., \& Rallis, S.R. (1991). Factors and influences on high school students' career choices. Journal for Research in Mathematics Education, 22(4), 281-292.

9- Esterberg, K. (2002). Qualitative methods in social research. New York: McGraw-Hill. 10- Good, T.L., \& Brophy, J.E. (1994). Looking in classrooms (6th ed.). New York: HarperCollins.

11- Goodlad, J.I. (1983). A summary of a study of schooling: Some findings and hypotheses. Phi Delta Kappan, 64(7), 465-470.

12- Goodlad, J.I. (1990). Teachers for our nation's schools. San Francisco, CA: Jossey-Bass Inc.

13- Gorham, J., \& Christophel, D. M. (1990). The relationship of teachers' use of humor in the classroom to immediacy and student learning. Communication Education, 39, 354-368. 14- James, D. (2007). A need for humor in online courses. College Teaching, 52(3), 93-94. 15- Jussim, L., \& Eccles, J. S. (1992). Teacher expectations II: Construction and reflection of student achievement. Journal of Personality and Social Psychology, 63(3), 947-961.

16- Kher, N., Molstad, S., \& Donahue, R. (1999). Using humor in the college classroom to enhance teaching effectiveness in "dread courses." College Student Journal, 33(3), 400-406. 
17- Lortie, D. (1975). Schoolteacher: A sociological study. Chicago: University of Chicago Press.

18- Malikow, M. (2006). Effective teacher study. National Forum of Teacher Education Journal-Electronic, 16(3), 1-9.

19- Mehrabian, A. (1968). Communication without words. Psychology Today, 2 (9), 52-55.

20- Merriam, S. (2002). Qualitative research in practice: Examples for discussion and analysis. San Francisco: Jossey-Bass.

21- Neill, S., \& Caswell, C. (1993). Body language for competent teachers. London: Routledge.

22- Nussbaum, J.F. (1992). Effective teacher behaviors. Communication Education, 41(2), 167-180.

23- Penick, J.E., Yager, R.E., \& Bonnstetter, R.J. (1986). Teachers make exemplary programs. Educational Leadership, 44, 14-20.

24- Reichel, N. \& Arnon, S. (2009). A multicultural view of the good teacher in Israel. Teachers and Teaching: Theory and Practice, 15(1), 59-85.

25- Snyder, L. G., \& McNeil, K. R. Enhancing students' perceptions of collaborative projects through the use of pre-group instruction methods.

26- Taylor, Eric (2004), Improve your personality, Poole-Dorsed, UK: Javelin Books

27- Utarid. W(1972), An Introduction to Educational Sociology, Palayamkottai, TN: St Xavier's Publications

28- Wong, H.K, \& Wong, R.T. (1998). The first days of school. Mountain View, CA: Harry K. Wong Publications, Inc.

29- Wray, D., Medwell, J., Fox, R., \& Poulson, L. (2000). The teaching practices of effective teachers of literacy. Educational Review, 52(1), 75-84

30- https://www.maharishiphotos.com /lecture32.html

31- http://www.saieditor.com/falco/values.html 